\title{
Chitinase-producing Salinivibrio bacteria isolated from salt-fermented shrimp with antimicrobial and safety assessments
}

\author{
Bao Le ${ }^{1} \cdot$ Gyuhwa Chung ${ }^{1} \cdot$ Seung Hwan Yang ${ }^{1}$
}

Received: 23 May 2018 / Accepted: 26 July 2018 / Published Online: 30 September 2018

(C) The Korean Society for Applied Biological Chemistry 2018

\begin{abstract}
Chitinases are glycosyl hydrolases which cleave the $\beta$ 1,4 linkage of chitin into oligo or monomers of $\mathrm{N}$-acetylglucosamine. These bacterial enzymes have been used for a wide range of applications in the food and pharmaceutical industries. In this study, we isolated two potential chitinolytic strains, BAO-01 and BAO-02, from salt-fermented shrimp, which were shown to belong to the genus Salinivibrio through genetic characterization using $16 \mathrm{~S}$ rRNA. These isolates were gram-positive, rod-shaped, and non-spore forming. BAO-01 showed greater growth and chitinase activity than BAO- 02 after the incubation at $37^{\circ} \mathrm{C}$ for 4 days. Both strains grew on a wide range of carbon and nitrogen sources, $\mathrm{pH}$ values, temperatures, and salt levels. However, they showed minor biochemical differences. In addition, their antimicrobial activities against foodborne pathogens and antibiotic susceptibilities were evaluated. These Salinivibrio spp. did not show bioamine production, hemolytic activity, and mucin degradation. Therefore, the in vitro screening results suggested that these bacteria could be widely used as new candidates for chitin hydrolyzation and seafood fermentation.
\end{abstract}

Keywords Antimicrobial $\cdot$ Chitinase $\cdot$ Food safety $\cdot$ Salinivibrio · salt-fermented shrimp

Seung Hwan Yang $(\bowtie)$

E-mail: ymichigan@jnu.ac.kr

${ }^{1}$ Department of Biotechnology, Chonnam National University, Yeosu 59626, Republic of Korea

This is an Open Access article distributed under the terms of the Creative Commons Attribution Non-Commercial License (http://creativecommons. org/licenses/by-nc/3.0/) which permits unrestricted non-commercial use, distribution, and reproduction in any medium, provided the original work is properly cited.

\section{Introduction}

Jeotgal is a traditional Korean salted and fermented seafood that is used both as a food additive and as a food. Jeotgal has been shown to be a potential functional food with therapeutic properties such as has shown to be a potential bioactive functional food by antidiabetics, anticancer, antiobesity and immunomodulatory in vivo [1]. It is prepared from various fish, fish eggs, shellfish, fish intestines, oyster, and shrimp, which are mixed with $10-30 \%(\mathrm{w} / \mathrm{w})$ salt and stored for several months at $15-25^{\circ} \mathrm{C}$ [2]. Among the various types, jeotgal prepared from anchovies and small shrimp contains the highest levels of valuable chitooligosaccharides due to the digestion of scale and shells by chitinase enzyme produced from bacteria during fermentation $[3,4]$. Therefore, the isolation of bacteria with strong chitinase activity is important for improving the commercial quality of fermented foods and developing novel enzymes with industrial potential.

Chitinase (EC 3.2.11.14) are glycosyl hydrolases which hydrolyze $\beta-1,4$ linkage of chitin have been detected in numerous bacteria, fungi, insects, plants, and animals [4]. Among them, bacterial chitinases have been implicated in the utilization of chitin as a carbon source and protection against pathogens. In recent years, chitinases produced by bacteria have been received increased attention due to a wide spectrum of properties and activities [5]. Although many bacterial chitinases have been reported, safety and efficiency issues of bacteria and their chitinase remains poorly characterized in food application [6].

Until now, the use of high salt content in shrimp fermentation is a challenge cause of the selection of salt tolerant bacteria as a starter culture. Screening for novel strains with specific properties and technologies, therefore, is still of great interest to improve the chitinase production in order to meet the increasing demand for traditional food. We recently isolated and identified a novel chitinolytic Salinivibrio strain from fermented salted shrimp in Yeosu, Korea. Their morphological, biochemical characteristic and $16 \mathrm{~S}$ rDNA gene of the isolated strains were evaluated. In 
addition, the potential of these Salinivibrio strains for inhibiting foodborne pathogens and the in vitro safety were also assessed.

\section{Material and Methods}

\section{Isolation and identification of chitinase producing strains}

Jeotgal samples containing fresh shrimp fermented with low salt (15-20\%) for 12 weeks were collected from a local market in Yeosu, serially diluted, and spread on marine agar (Difco, Detroit, MI, USA) supplemented with $0.5 \%(\mathrm{w} / \mathrm{v})$ colloidal chitin. After a 5-d incubation period at 30 and $37{ }^{\circ} \mathrm{C}$, the colonies producing a distinct clear zone were selected as chitin degrading ability. Isolates were randomly selected based on morphological differences and streak purified on marine agar. All isolates were examined by Gram staining, catalase activity, carbohydrate fermentation, and enzyme activities using the API 50CHL and API ZYM systems (bioMérieux, Durham, NC, USA).

The genomic DNA of isolates was extracted using the genomic DNA preparation Kit (SolGent, Daejeon, Korea), according to the manufacturer's instructions. PCR was performed using the universal primers [7], 27F (5'-AGAGTTTGATCCTGGCTCAG3') and 1492R (5'-GGTTACCTTGTTACGACTT-3'), in a Takara Thermal Cycler Dice (TP-800; Takara, Shiga, Japan). Each 25- $\mu \mathrm{L}$ reaction contained $1 \mathrm{U}$ of Taq polymerase (Takara), $0.5 \mu \mathrm{M}$ of each primer, $1 \mu \mathrm{M}$ dNTPs, $2.5 \mu \mathrm{M} \mathrm{MgCl}$, and template DNA. PCR tubes were preheated at $94{ }^{\circ} \mathrm{C}$ for $7 \mathrm{~min}$, and then the following amplification program was run: 30 cycles of $94{ }^{\circ} \mathrm{C}$ for $30 \mathrm{~s}, 50{ }^{\circ} \mathrm{C}$ for $45 \mathrm{~s}$, and $72{ }^{\circ} \mathrm{C}$ for $30 \mathrm{~s}$. The PCR products $(5 \mu \mathrm{L})$ were run on a $1 \%$ agarose gel and visualized with a UV illuminator. The amplified PCR products were purified using the AccuPrep $^{\circledR}$ PCR Purification Kit (Bioneer, Daejeon, Korea) according to the manufacturer's instructions. Then, the purified PCR products were sequenced and assembled. The 16S rRNA sequences of two isolated strains (BAO-01 and BAO-02) were deposited in GenBank with accession numbers KX990293 and KX990294, respectively. The $27 \mathrm{~F}$ and $1492 \mathrm{R}$ primers were also used for sequencing. A phylogenetic tree was constructed with MEGA v.7.0 [8] using the neighbor joining (NJ) method and 1000 replicates for the bootstrap analysis.

Effects of $\mathrm{pH}$, temperature, and $\mathrm{NaCl}$ concentration on cell growth The isolated strains were cultured in marine broth (Difco) containing $0.1 \%(\mathrm{w} / \mathrm{v})$ colloidal chitin $(\mathrm{MB}-\mathrm{C})$ for $6 \mathrm{~d}$. To investigate the effect of temperatures and $\mathrm{pH}$, the incubation was carried out at $20,30,37$, and $50{ }^{\circ} \mathrm{C}$ in medium adjusted to $\mathrm{pH} 3$, 4, 5, 6, 7, 8, 9, and 10 (with $0.1 \mathrm{M} \mathrm{HCl}$ and/or $\mathrm{NaOH}$ before autoclaving). To assess salt tolerance, MB-C medium was supplemented with $10-20 \% \mathrm{w} / \mathrm{v} \mathrm{NaCl}$. Growth was assessed by measuring the absorbance at $600 \mathrm{~nm}$ with a spectrophotometer.

Effect of carbon and nitrogen source on chitinase production
Chitinase production was assessed after growth in $100 \mathrm{~mL}$ of MB$\mathrm{C}$ medium containing $1 \%(\mathrm{w} / \mathrm{v})$ of various carbon sources (galactose, mannitol, starch, fructose, sucrose, glucose, and dextrose) and nitrogen sources (urea, yeast extract, peptone, malt extract, gelatin, ammonium sulfate, and casein). Then, the medium was inoculated with the isolated strains $(10 \% \mathrm{v} / \mathrm{w}$; $\mathrm{OD}=0.5$ ) and incubated at $37^{\circ} \mathrm{C}$ for $48 \mathrm{~h}$. After fermentation, cell growth and chitinase activity were assessed.

\section{Preparation of colloidal chitin}

Colloidal chitin was prepared from shrimp shell chitin (Sigma, St. Louis, MO, USA). Briefly, $10 \mathrm{~g}$ of powdered chitin was suspended in $100 \mathrm{~mL}(\mathrm{v} / \mathrm{w})$ of $10 \mathrm{~N} \mathrm{HCl}$, mixed, and incubated at $4{ }^{\circ} \mathrm{C}$ overnight. Then, $1.9 \mathrm{~L}$ of $100 \%$ ethanol was added and incubated at $-20{ }^{\circ} \mathrm{C}$ overnight to allow precipitation. The precipitates were collected by centrifuge at $8000 \times g$ for $15 \mathrm{~min}$ at $4{ }^{\circ} \mathrm{C}$. The colloidal chitin was washed with sterile distilled water until a neutral $\mathrm{pH}$ was achieved, and then freeze-dried to a powder and stored at $4{ }^{\circ} \mathrm{C}$.

\section{Enzyme assay}

A chitinase assay was carried out using colloidal chitin as a substrate according to the method of [9]. The chitinase enzyme sample was incubated with colloidal chitin (final concentration of $2 \mathrm{mg} / \mathrm{mL}$ ) for $1 \mathrm{~h}$ at $40^{\circ} \mathrm{C}$. The reaction was stopped by incubating in a boiling water for $10 \mathrm{~min}$, followed by centrifugation at $10000 \times g$ for $5 \mathrm{~min}$. The reducing sugar content was estimated using the dinitrosalicylic acid (DNS) method [10] at $540 \mathrm{~nm}$ using $\mathrm{N}$-acetyl- $\beta$-D-glucosamine (GlcNAc) as the standard. One unit of enzyme activity was defined as the amount of enzyme that released $1 \mu \mathrm{mol}$ of GlcNAc per hour.

\section{Determination of antibiotic susceptibility}

The minimum inhibitory concentrations of various antibiotics were determined by the broth microdilution method in 96-well plates as described previously [11]. Briefly, isolates were grown in marine broth at $37^{\circ} \mathrm{C}$ overnight to a final density of $10^{7} \mathrm{CFU} / \mathrm{mL}$. All tested antibiotics were serially diluted 2-fold (256 to $0.5 \mathrm{mg}$ / L) using marine broth in the plate. Then, the bacteria suspension was filled up to $200 \mu \mathrm{L}$. The positive controls contained no antibiotic. After $24 \mathrm{~h}$ incubation at $37{ }^{\circ} \mathrm{C}$, the lowest concentration of an antimicrobial substance that visibly inhibited growth was recorded.

\section{Antimicrobial activity}

The antimicrobial activity of the new isolates was determined by the disk diffusion method on nutrient agar [12]. The foodborne microbial pathogens used in this study were obtained from microbial culture collection centers in the Republic of Korea, such as the Korean Collection for Type Cultures, Korean Agricultural Culture Collection (KACC), and Korean Culture Collection of Microorganisms. Standard inoculum $\left(10^{7} \mathrm{CFU} / \mathrm{mL}\right)$ of each pathogen 
was spread onto the surface of a nutrient agar plate. Cell-free supernatant $(100 \mu \mathrm{L})$ from the isolates was loaded on 8-mm paper discs, dried, and then placed on the inoculated nutrient agar plate. The plates were incubated at $37^{\circ} \mathrm{C}$ for $24 \mathrm{~h}$, and then the inhibitory zones were measured. The uncultured media was used as a control.

\section{Safety assessment}

To test the safety of these newly isolated strains, biogenic amine production, mucin degradation, and hemolytic activity were examined according to the methods of [13], Zhou, Gopal and Gill [14] and Semedo, Santos, Martins, Lopes, Marques, Tenreiro and Crespo [15] respectively. To determine bioamine production, isolate colonies were streaked on decarboxylase medium prepared with or without amino acids $(0.5 \% \mathrm{w} / \mathrm{v})$. Mucin degradation was examined using agarose medium containing $0.3 \%$ mucin with or without glucose $(\mathrm{g} / \mathrm{L})$, and hemolytic activity was tested using blood base agar medium containing 5\% defibrinated sheep blood (Thermo Fisher Scientific, Waltham, MA, USA). All plates were incubated for $24 \mathrm{~h}$ at $37^{\circ} \mathrm{C}$.

\section{Statistical analysis}

The SPSS software ver. 22 (SPSS Inc., Chicago, IL, USA) was used to perform all statistical analysis including One-way analysis of variance (ANOVA) and Duncan Post-hoc test $(p<0.05)$. Results are presented as mean \pm SD (standard deviation) with at least three times replications.

\section{Results and Discussion}

\section{Identification by biochemical and genetics analyses}

A total of 50 morphologically different bacterial colonies were isolated from five samples of jeotgal. Two of these colonies produced a clear zone on marine agar supplemented with colloidal chitin and were selected for additional screening. These candidate isolates, named $\mathrm{BAO}-01$ and $\mathrm{BAO}-02$, were characterized morphologically, biochemically, and genetically. Both strains is a rod-shaped organism thought out the shape suggested that the BAO-01 cell were longer than those of BAO-02. Both strains were gram-negative and did not produce spores.

The biochemical tests were primarily analyzed to investigate the identity of the isolates, as well as the effects of $\mathrm{pH}$, temperature, and $\mathrm{NaCl}$ concentration on growth also was estimated (Table 1). These isolates were catalase positive. Although both strains grew in the presence of high concentrations of salt, BAO-02 also grew well in the absence of $\mathrm{NaCl}$. Growth was observed at $10-50{ }^{\circ} \mathrm{C}$, with optimal growth at $37^{\circ} \mathrm{C}$. The $\mathrm{pH}$ range for growth was 4.0 8.0 , but BAO-01 also grew at basic conditions $(>8.0)$, with optimal growth at $\mathrm{pH}$ 7.5. Although both strains showed the utilizing abilities in a wide range of carbon sources; strain BAO01 was able to utilize xylose, mannose, cellobiose, and saccharose,
Table 1 Physiological and biochemical characteristics of the isolated strains from salted and fermented shrimp based on the API $50 \mathrm{CH}$ system and additional tests after $24 \mathrm{~h}$ at $37^{\circ} \mathrm{C}$

\begin{tabular}{|c|c|c|}
\hline & $\begin{array}{c}\text { Salinivibrio sp. } \\
\text { BAO-01 }\end{array}$ & $\begin{array}{c}\text { Salinivibrio sp. } \\
\text { BAO-02 }\end{array}$ \\
\hline Catalase & + & + \\
\hline \multicolumn{3}{|l|}{$\mathrm{NaCl}$ for growth $(\%, \mathrm{v} / \mathrm{w})$} \\
\hline Range & $5-20$ & $0-20$ \\
\hline Optimum & 5 & 5 \\
\hline \multicolumn{3}{|l|}{ Temperature for growth $\left({ }^{\circ} \mathrm{C}\right)$} \\
\hline Range & $10-50$ & $10-50$ \\
\hline Optimum & 37 & 37 \\
\hline \multicolumn{3}{|l|}{$\mathrm{pH}$ for growth } \\
\hline Range & $4.0-9.5$ & $4.0-8.0$ \\
\hline Optimum & 7.5 & 7.5 \\
\hline \multicolumn{3}{|l|}{ Carbohydrates } \\
\hline D-Ribose & + & + \\
\hline D-Xylose & + & - \\
\hline D-Galactose & + & - \\
\hline D-Glucose & + & + \\
\hline D-Fructose & - & + \\
\hline D-Mannose & + & - \\
\hline D-Mannitol & + & - \\
\hline N-Acetyl-glucosamine & + & + \\
\hline D-Cellobiose & + & - \\
\hline D-Maltose & - & + \\
\hline D-Lactose & - & + \\
\hline D-Saccharose & + & - \\
\hline Starch & + & + \\
\hline Glycogene & + & + \\
\hline Gluconate & + & - \\
\hline 2-keto-Gluconate & - & + \\
\hline
\end{tabular}

which could be not utilized by BAO-02 (Table 1).

The 16S rRNA gene sequence of the chitinolytic isolates was analyzed for molecular identification. The nearly complete $16 \mathrm{~S}$ rRNA sequences of BAO-01 (1460 bases; GenBank accession no. KX990293) and BAO-02 (1473 bases; GenBank accession no. KX990294) were determined. The BAO-01 strain closely resembled Salinivibrio costicola E-367 (X95529) and Salinivibrio vallismortis (AF057016), with 92.20 and $91.78 \%$ sequence similarity, respectively (Fig. 1). BAO-02 showed 88.15 and $87.62 \%$ similarity with $S$. costicola E-367 (X95529) and S. vallismortis (AF057016), respectively. The Salinivibrio clade was also supported by high bootstrap value (99\%). Based on pairwise 16S rRNA gene comparisons, the chitinolytic strains BAO-01 and BAO-02 represent the novel genus, with the proposed name Salinivibrio. Species belonging to the genus Salinivibrio have been isolated from a variety of natural sources, including lakes, marine environments, and foods [16-18]. The gram-negative bacteria in the genus Salinivibrio have been shown to secrete a number of degradative enzymes, including cellulase, lipase, protease, chitinase [19-22]. 


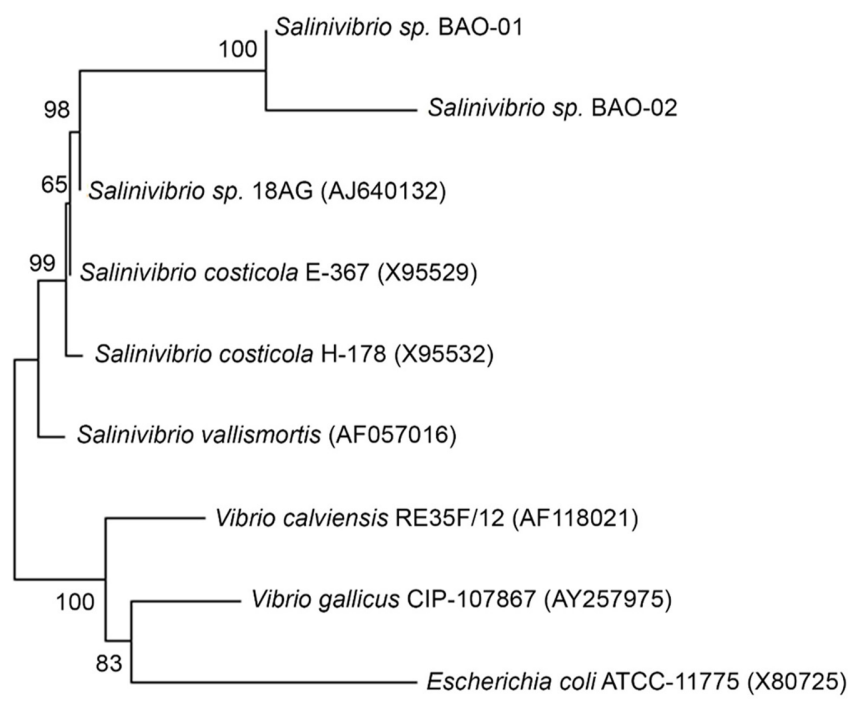

$$
\stackrel{\longmapsto}{0.01}
$$

Fig. 1 A phylogenetic tree generated by the neighbor joining method showing the relationships between theisolated Salinivibrio strains and related taxa based on 16S rRNA gene sequences. 1000 replications were used forthe bootstrap analysis. Bar, 0.01 substitutions per nucleotide position

However, in the present study, we report the isolation and identification of two novel Salinivibrio strains with chitinase activity isolated from fermented and salted shrimp food in Korea.

\section{Chitinase production from isolated strains}

Studies were undertaken to evaluate the chitinase production of these strains during growth. The isolates were grown in marine broth containing $0.1 \%$ colloidal chitin at $37{ }^{\circ} \mathrm{C}$ for $4 \mathrm{~d}$. The BAO01 strain grew exponentially better than the BAO-02 strain after $12 \mathrm{~h}$, when it reached maximum growth, and remained steady $\left(\mathrm{OD}_{600}=1.36\right)$ until $48 \mathrm{~h}$ (Fig. 2). In a time course study, BAO-01 showed maximum chitinase production $(19.02 \mathrm{U} / \mathrm{mL})$ at $48 \mathrm{~h}$ of incubation, after which enzyme concentration gradually decreased (at $72 \mathrm{~h}$ ), as shown in Fig. 2. BAO-02 produced high levels of chitinase $(15.56 \mathrm{U} / \mathrm{mL})$ as the cells grew $\left(\mathrm{OD}_{600}=0.91\right)$ at $36 \mathrm{~h}$, but then showed a steady decline beginning at $72 \mathrm{~h}$ of cultivation. In contrast, many other bacteria reached maximal chitinase activity and protease secretion during stationary phase growth, when the cell density started to decline [23,24].

\section{Carbon and nitrogen sources on chitinase production}

The effects of medium supplemented with fourteen carbon and nitrogen sources $(1 \% \mathrm{w} / \mathrm{w})$ on chitinase production by Salinivibrio BAO-01 and BAO-02 are shown in Fig. 3. The mechanism of enzyme production on carbon and nitrogen is still not clear, the correlation can vary depending on bacteria species. For the carbon sources, the Salinivibrio strains showed maximum chitinase activity during growth on sucrose, glucose, and dextrose. Kim, Ki, Lim, Vijayakumar, Park, Choi, Kim, Im and Park [25] observed the same result with glucose, sucrose, which had effective to enhance the production by Acinetobacter parvus HANDI 309. With all tested carbon sources tested, BAO-01 produced significantly $(p<0.05)$ higher chitinase than BAO-02, except in galactose, mannitol, and starch.

Ammonium sulfate, an inorganic nitrogen source, supported significantly higher $(p<0.05)$ chitinase yields in both strains. Another study showed that high concentrations ( $4.2 \mathrm{~g} / \mathrm{L})$ of chitin and ammonium sulfate enhanced chitinase production by Trichoderma harzianum [26]. Among the organic nitrogen sources tested, casein, along with a reasonable quantity of yeast extract, supported maximum chitinase production. The same findings were also reported with Amorphoscelis punctata HS6 [27]. In contrast, cultivation in peptone, malt extract, and gelatin drastically decreased chitinase activity but these nitrogen sources enhanced enzyme production in the case of A. punctata HS6 [27]. Similar observations have also been described by Singh, Mehta and Chhatpar [28] in Paenibacillus sp. D1.

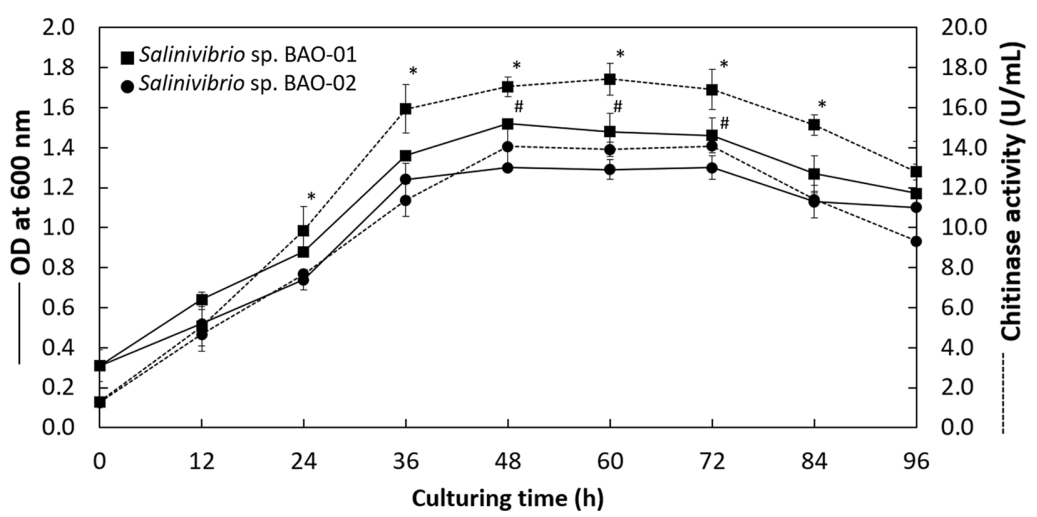

Fig. 2 Time course of chitinase production by Salinivibrio sp. BAO-01 and BAO-02 in MA-C medium. ${ }^{*} p<0.05$ statistical significance between two strains in OD value and ${ }^{\#} p<0.05$ statistical significance between two strainsin chitinase activity 


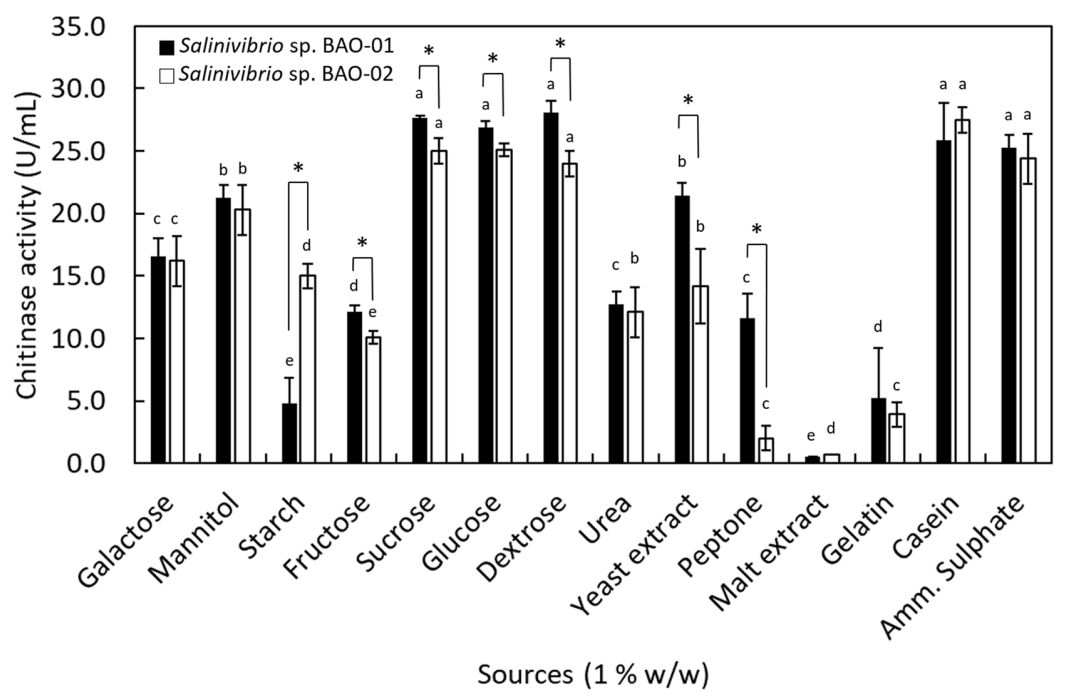

Fig. 3 Effect of carbon and nitrogen source on the chitinase activity of Salinivibrio sp. BAO-01 and BAO-02.Values in the same column and in same carbon or nitrogen sources with different superscripted alphabet aresignificantly different at $p<0.05$. ${ }^{*} p<0.05$ statistical significance between two strains

\section{Safety use of isolated strains}

The antimicrobial activities of the isolated Salinivibrio strains against various foodborne pathogens were evaluated (Table 2). Salinivibrio BAO-01 and BAO-02 showed the highest inhibitory activities against Escherichia coli and Yersinia enterocolitica. The tests showed that these Salinivibrio strains have broad spectrum antimicrobial activities against both gram-positive and gramnegative species. The antimicrobial susceptibility testing showed that both Salinivibrio isolates strains were inhibited by penicillin (4 $\mu \mathrm{g} / \mathrm{mL})$, ampicillin $(1 \mu \mathrm{g} / \mathrm{mL})$, and streptomycin $(4-8 \mu \mathrm{g} / \mathrm{mL}$; Table 2). BAO-01 and BAO-02 showed resistance to vancomycin and kanamycin. Amoozegar, Schumann, Hajighasemi, Fatemi and Karbalaei-Heidari [29] showed that Salinivibrio proteolyticus was resistant to kanamycin (30 mg), penicillin $\mathrm{G}(10 \mathrm{U})$, and streptomycin (10 mg). In addition, a Salinivibrio siamensis strain isolated from fermented fish was inhibited by $10 \mathrm{mg}$ of ampicillin [30]. To address the safety of these newly isolated bacterial strains before application in functional foods as a starter culture, food preservative, and probiotic, these Salinivibrio spp. were tested to assess various safety aspects, such as hemolytic activity, bioamine production, and mucin degradation activity. B. cereus KACC 11240 was used as positive control pathogen (Supplementary material 1). All safety aspects were negative results in Table 2. However further whole genome analyses of these newly isolated strains are recommended.

Two strains isolated from a fermented and salted shrimp food were selected for their chitinase-producing ability. Theses isolated were identified by 16S rRNA gene sequencing as Salinivibrio sp. BAO-01 and BAO-02. Their morphology, biochemical characteristics, and optimum growth conditions were investigated. The search for new food-safe chitinase-producing Salinivibrio with a wider spectrum of antimicrobial activities for use as starter inoculum may improve food quality and reduce microbial contamination. Further explorations on developing large-scale chitinase production and effect of Salinivibrio in fermented food need to confirm.

Acknowledgments This work (Grants No. C0499996) was supported by Business for Cooperative R\&D between Industry, Academy, and Research Institute funded Korea Small and Medium Business Administration in 2017.

Table 2 Antimicrobial activity of cell free supernatant broth of isolates against common pathogens, antibiotic resistances, and safety assessment

\begin{tabular}{|c|c|c|c|}
\hline & & $\begin{array}{c}\text { Salinivibrio sp. } \\
\text { BAO-01 }\end{array}$ & $\begin{array}{l}\text { Salinivibrio sp. } \\
\text { BAO-02 }\end{array}$ \\
\hline \multirow{9}{*}{$\begin{array}{l}\text { Indicator } \\
\text { strains }^{\mathrm{a}}\end{array}$} & B. cereus & ++ & ++ \\
\hline & E. coli $\mathrm{K} 99$ & +++ & +++ \\
\hline & L. monocytogenes & + & + \\
\hline & S. gallinarum & + & ++ \\
\hline & S. aureus & ++ & ++ \\
\hline & S. choleraesuis & ++ & + \\
\hline & S. typhi & + & + \\
\hline & S. boydii & ++ & + \\
\hline & Y. enterocolitica & +++ & ++ \\
\hline \multirow{6}{*}{$\begin{array}{c}(\mathrm{MIC})^{\mathrm{b}} \\
(\mu \mathrm{g} / \mathrm{mL})\end{array}$} & Penicillin & 4 & 4 \\
\hline & Ampicillin & 1 & 1 \\
\hline & Vancomycin & 64 & 64 \\
\hline & Streptomycin & 4 & 8 \\
\hline & Kanamycin & 16 & 8 \\
\hline & Tetracycline & 64 & 64 \\
\hline \multicolumn{2}{|c|}{ Bioamine production } & ND & ND \\
\hline \multicolumn{2}{|c|}{ Hemolytic activity } & ND & ND \\
\hline \multicolumn{2}{|c|}{ Mucin degradation } & ND & ND \\
\hline
\end{tabular}

+: $4 \mathrm{~mm}$; ++: $8 \mathrm{~mm}$; +++: zone $>8 \mathrm{~mm}$

ND: non-detected 
Conflict of interest statement We declare that we have no conflicts of interest.

\section{References}

1. Koo OK, Lee SJ, Chung KR, Jang DJ, Yang HJ, Kwon DY (2016) Korean traditional fermented fish products: jeotgal. J Ethn Foods 3: 107116

2. Guan L, Cho KH, Lee J-H (2011) Analysis of the cultivable bacterial community in jeotgal, a Korean salted and fermented seafood, and identification of its dominant bacteria. Food Microbiol 28: 101-113

3. Chandrasekaran M, Enzymes in food and beverage processing (2015) CRC Press, Boca Raton

4. Adrangi S, Faramarzi MA (2013) From bacteria to human: a journey into the world of chitinases. Biotechnol Adv 31: 1786-1795

5. Yan Q, Fong SS (2015) Bacterial chitinase: nature and perspectives for sustainable bioproduction. Bioresour Bioprocess 2: 31

6. Bhattacharya D, Nagpure A, Gupta RK (2007) Bacterial chitinases: properties and potential. Crit Rev Biotechnol 27: 21-28

7. Lane D (1991) 16S/23S rRNA sequencing, Wiley, Chichester, UK

8. Kumar S, Stecher G, Tamura K (2016) MEGA7: Molecular evolutionary genetics analysis version 7.0 for bigger datasets. Mol Biol Evol 33: $1870-1874$

9. Monreal J, Reese ET (1969) The chitinase of Serratia marcescens. Can J Microbiol 15: 689-696

10. Miller GL (1959) Use of dinitrosalicylic acid reagent for determination of reducing sugar. Anal Chem 31: 426-428

11. Wiegand I, Hilpert K, Hancock REW (2008) Agar and broth dilution methods to determine the minimal inhibitory concentration (MIC) of antimicrobial substances. Nat Protoc 3: 163-175

12. Bauer AW, Kirby WM, Sherris JC, Turck M (1966) Antibiotic susceptibility testing by a standardized single disk method. Am J Clin Pathol 45: 493

13. Bover-Cid S, Holzapfel WH (1999) Improved screening procedure for biogenic amine production by lactic acid bacteria. Int J Food Microbiol 53: $33-41$

14. Zhou JS, Gopal PK, Gill HS (2001) Potential probiotic lactic acid bacteria Lactobacillus rhamnosus (HN001), Lactobacillus acidophilus (HN017) and Bifidobacterium lactis (HN019) do not degrade gastric mucin in vitro. Int J Food Microbiol 63: 81-90

15. Semedo T, Santos MA, Martins P, Lopes MFS, Marques JJF, Tenreiro R, Crespo MTB (2003) Comparative study using type strains and clinical and food isolates to examine hemolytic activity and occurrence of the cyl operon in enterococci. J Clin Microbiol 41: 2569-2576

16. Kumar S, Karan R, Kapoor S, Singh SP, Khare SK (2012) Screening and isolation of halophilic bacteria producing industrially important enzymes. Braz J Microbiol 43: 1595-1603

17. Gorriti MF, Dias GM, Chimetto LA, Trindade-Silva AE, Silva BS, Mesquita MMA, Gregoracci GB, Farias ME, Thompson CC, Thompson FL (2014) Genomic and phenotypic attributes of novel salinivibrios from stromatolites, sediment and water from a high altitude lake. BMC Genomics 15: 473

18. Sanchart C, Benjakul S, Rattanaporn O, Haltrich D, Maneerat S (2015) Efficiency of the V3 region of $16 \mathrm{~S}$ rDNA and the rpoB gene for bacterial community detection in Thai traditional fermented shrimp (Kung-Som) using PCR-DGGE techniques. Songklanakarin J Sci Technolog 37: 291297

19. Wang C-Y, Hsieh Y-R, Ng C-C, Chan H, Lin H-T, Tzeng W-S, Shyu Y$\mathrm{T}$ (2009) Purification and characterization of a novel halostable cellulase from Salinivibrio sp. strain NTU-05. Enzyme Microb Technol 44: 373379

20. Amoozegar MA, Salehghamari E, Khajeh K, Kabiri M, Naddaf S (2008) Production of an extracellular thermohalophilic lipase from a moderately halophilic bacterium, Salinivibrio sp. strain SA2. J Basic Microbiol 48: 160-167

21. Lama L, Romano I, Calandrelli V, Nicolaus B, Gambacorta A (2005) Purification and characterization of a protease produced by an aerobic haloalkaliphilic species belonging to the Salinivibrio genus. Res Microbiol 156: 478-484

22. Aunpad R, Panbangred W (2003) Cloning and characterization of the constitutively expressed chitinase $\mathrm{C}$ gene from a marine bacterium, Salinivibrio costicola strain 5SM-1. J Biosci Bioeng 96: 529-536

23. Vaidya RJ, Shah IM, Vyas PR, Chhatpar HS (2001) Production of chitinase and its optimization from a novel isolate Alcaligenes xylosoxydans: potential in antifungal biocontrol. World J Microbiol Biotechnol 17: 691-696

24. Han KI, Patnaik BB, Kim YH, Kwon HJ, Han YS, Han MD (2014) Isolation and characterization of chitinaseproducing Bacillus and Paenibacillus strains from salted and fermented shrimp, Acetes japonicus. J Food Sci 79

25. Kim TI, Ki KS, Lim DH, Vijayakumar M, Park SM, Choi SH, Kim KY, Im SK, Park BY (2017) Novel Acinetobacter parvus HANDI 309 microbial biomass for the production of $\mathrm{N}$-acetyl- $\beta$-D-glucosamine (GlcNAc) using swollen chitin substrate in submerged fermentation. Biotechnology for biofuels 10: 59

26. Kapat A, Rakshit SK, Panda T (1996) Optimization of carbon and nitrogen sources in the medium and environmental factors for enhanced production of chitinase by Trichoderma harzianum. Bioprocess Eng 15: $13-20$

27. Kuddus M, Ahmad I (2013) Isolation of novel chitinolytic bacteria and production optimization of extracellular chitinase. Journal of Genetic Engineering and Biotechnology 11: 39-46

28. Singh A, Mehta G, Chhatpar H (2009) Optimization of medium constituents for improved chitinase production by Paenibacillus sp. D1 using statistical approach. Lett Appl Microbiol 49: 708-714

29. Amoozegar MA, Schumann P, Hajighasemi M, Fatemi AZ, KarbalaeiHeidari HR (2008) Salinivibrio proteolyticus sp. nov., a moderately halophilic and proteolytic species from a hypersaline lake in Iran. Int J Syst Evol Microbiol 58: 1159-1163

30. Chamroensaksri N, Tanasupawat S, Akaracharanya A, Visessanguan W, Kudo T, Itoh T (2009) Salinivibrio siamensis sp. nov., from fermented fish (pla-ra) in Thailand. Int J Syst Evol Microbiol 59: 880-885 